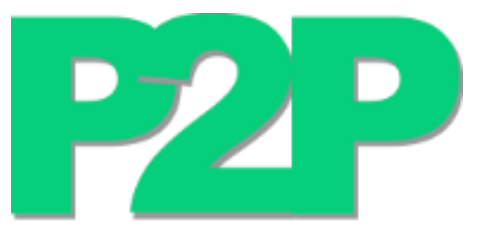

G INOVAÇÃo

\title{
EXPEDIENTE/EDITORIAL TEAM
}

v.6, n. 2, Edição Especial, 2020

\begin{tabular}{|c|c|}
\hline EDITOR GERAL / EDITOR & $\begin{array}{c}\text { Clovis Montenegro de Lima } \\
\text { http://lattes.cnpq.br/4727891485011869 }\end{array}$ \\
\hline $\begin{array}{l}\text { EDITORES ASSISTENTES / } \\
\text { ASSISTANT EDITORS }\end{array}$ & 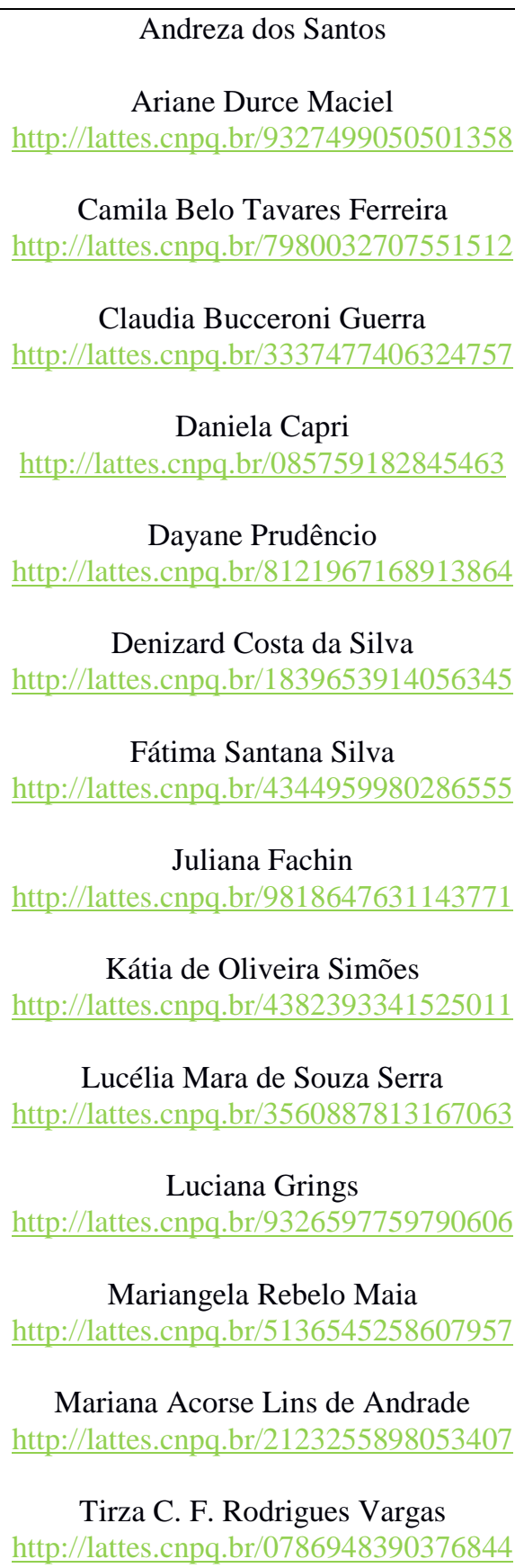 \\
\hline
\end{tabular}

